\title{
Duroc Pig
}

National Cancer Institute

\section{Source}

National Cancer Institute. Duroc Pig. NCI Thesaurus. Code C77101.

An older breed of American domestic pig, the Duroc breed is of medium length with a muscular, large-framed body. This pig breed is red-colored with partially drooping ears and is one of the most aggressive breeds of swine. The Duroc breed is also one of the largest sized breeds in use in biomedical research but its size and temperament make it a less popular choice in research. 